\title{
Clinical and Radiological Characterization of Progressive Multifocal Leukoencephalopathy in HIV-Infected Patients: A Retrospective Analysis and Review of the Literature
}

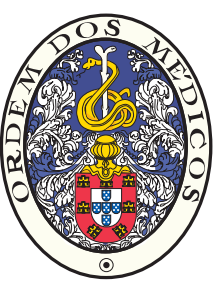

\author{
Caraterização Clínica e Radiológica dos Doentes com Leucoencefalopatia \\ Multifocal Progressiva Infetados pelo Vírus da Imunodeficiência Humana: \\ Análise Retrospetiva e Revisão da Literatura
}

\author{
Luís AUGUSTO ${ }^{1}$, Nélia NEVES ${ }^{2}$, Carina REIS ${ }^{1}$, Cândida ABREU², António SARMENTO ${ }^{2,3}$ \\ Acta Med Port 2015 May-Jun;28(3):286-296
}

\section{ABSTRACT}

Introduction: Progressive multifocal leukoencephalopathy is a demyelinating disease of the central nervous system caused by John Cunningham virus, mostly associated with immunodeficiency conditions, such as the human immunodeficiency virus infection. Progressive multifocal leukoencephalopathy can have multiple clinical features and usually presents a typical lesion pattern on brain magnetic resonance imaging. Its course may be rapidly progressive, although immunological responsiveness can be associated with an improved prognosis.

Material and Methods: We performed a retrospective analysis of the clinical and radiological data from patients admitted in our institution between January 2005 and April 2014 with the diagnosis of definitive progressive multifocal leukoencephalopathy (ICD10:A81.2) in the setting of human immunodeficiency virus infection.

Results: Twenty-one patients were included in our study, mostly men $(n=20,95.2 \%)$. Mean age at diagnosis was 39 years. Motor deficits were the most common clinical finding. John Cunningham virus-DNA was detected in the cerebral spinal fluid in 20 patients $(95.2 \%)$. Brain imaging studies most commonly disclosed bilateral supratentorial, asymmetric lesions. Four (19\%) patients developed immune reconstitution inflammatory syndrome in the follow-up. Therapeutic approach included initiation and continuation/optimization of antiretroviral therapy, with adjunctive therapy with corticosteroids in four patients. Seventeen (81\%) patients died during the study period; median survival time following progressive multifocal leukoencephalopathy diagnosis was 3 months (range 1 - 13).

Discussion: The results of our study are in accordance with the data previously published on progressive multifocal leukoencephalopathy in human immunodeficiency virus patients. Progressive multifocal leukoencephalopathy is predominantly associated with severe immunosuppression, particularly in patients who are not under anti-retroviral therapy, and usually presents with motor and cognitive symptoms and signs. A typical bilateral asymmetric pattern in conventional magnetic resonance imaging is present in the majority of the patients. There is no specific therapy for progressive multifocal leukoencephalopathy and it is usually fatal, although outcomes can improve with highly active anti-retroviral therapy. Immune reconstitution inflammatory syndrome is also an important complication related with progressive multifocal leukoencephalopathy, usually associated with anti-retroviral therapy. Progressive multifocal leukoencephalopathy-immune reconstitution inflammatory syndrome presents with different imaging characteristics from progressive multifocal leukoencephalopathy and treatment with steroids can improve survival.

Conclusion: The mortality rate and long-term neurological morbidity associated with progressive multifocal leukoencephalopathy are quite high. These data should increase clinician awareness to the occurrence of progressive multifocal leukoencephalopathy among human immunodeficiency virus patients and highlight the important role of magnetic resonance imaging, as early diagnosis may be associated with better outcome.

Keywords: Antiretroviral Therapy, Highly Active; HIV Infections; Leukoencephalopathy, Progressive Multifocal/radiography; Magnetic Resonance Imaging.

\section{RESUMO}

Introdução: A leucoencefalopatia multifocal progressiva é uma patologia desmielinizante causada pelo vírus John Cunningham, geralmente associada a estados de imunodepressão, em particular a infeção pelo vírus da imunodeficiência humana. Pode apresentar múltiplas manifestações clínicas e tem habitualmente um padrão imagiológico típico. A evolução clínica é geralmente progressiva, podendo ocorrer uma melhoria do prognóstico associada à recuperação imunológica.

Material e Métodos: Foi conduzida uma análise retrospetiva dos dados clínicos e imagiológicos de doentes admitidos no nosso Hospital entre janeiro de 2005 e abril de 2014 com o diagnóstico de leucoencefalopatia multifocal progressiva (ICD10:A81.2) associado a infeção por vírus da imunodeficiência humana.

Resultados: Vinte e um doentes foram incluídos, sendo 20 do sexo masculino (95,2\%). A idade média na altura do diagnóstico foi 39 anos. A forma de apresentação mais frequente foi défice motor. O vírus John Cunningham foi identificado no líquido cefalorraquidiano em 20 doentes $(95,2 \%)$. Nos estudos de imagem verificou-se um predomínio de lesões supratentoriais, assimétricas e bilaterais. Quatro doentes (19\%) desenvolveram síndrome inflamatória de resposta imunológica. A abordagem terapêutica incluiu início ou otimização de terapêutica anti-retrovirica, associada a corticoterapia em quatro casos. Dezassete (81\%) doentes morreram no período do estudo, sendo a sobrevida mediana após diagnóstico de três meses (intervalo 1 a 13).

\footnotetext{
1. Neuroradiology Department. Centro Hospitalar São João. Porto. Portugal.

2. Infectious Diseases Department. Centro Hospitalar São João. Porto. Portugal.

3. Infectious Diseases Department. Faculty of Medicine. University of Porto. Porto. Portugal.

$\triangle$ Autor correspondente: Luís Pedro Augusto. luispmaugusto@gmail.com

Recebido: 31 de Outubro de 2014 - Aceite: 15 de Fevereiro de 2015 | Copyright $\odot$ Ordem dos Médicos 2015
} 
Discussão: Os resultados do nosso estudo são concordantes com os dados previamente publicados relativamente à leucoencefalopatia multifocal progressiva, evidenciando a sua associação à infecção pelo vírus da imunodeficiência humana, particularmente nos doentes com imunossupressão grave, o predomínio de sinais e sintomas motores e cognitivos, e a existência de um atingimento bilateral e assimétrico evidente nas sequências convencionais dos estudos de ressonância magnética. Não existe terapêutica específica e esta patologia é normalmente fatal, apesar de se verificar um aumento da sobrevida associado à terapêutica anti-retrovírica. A síndrome inflamatória de reconstituição imunológica é uma complicação associada a leucoencefalopatia multifocal progressiva, habitualmente ocorrendo após início de terapêutica anti-retrovírica, apresentando caraterísticas imagiológicas diferentes da leucoencefalopatia multifocal progressiva. A instituição de corticoterapia pode melhorar o prognóstico dos doentes que desenvolvem síndrome inflamatória de reconstituição imunológica associada a leucoencefalopatia multifocal progressiva.

Conclusão: A mortalidade e morbilidade associadas à leucoencefalopatia multifocal progressiva são elevadas, com sequelas neurológicas importantes a longo-prazo. Os dados apresentados deverão alertar os clínicos para a ocorrência desta patologia nos doentes com infecção vírus da imunodeficiência humana, evidenciando o papel cada vez mais determinante da Ressonância Magnética no diagnóstico precoce da leucoencefalopatia multifocal progressiva e consequente melhoria do prognóstico.

Palavras-chave: Leucoencefalopatia Multifocal Progressiva; Infecções por VIH; Ressonância Magnética; Terapêutica Anti-Retrovírica, Virus da Imunodeficiência Humana.

\section{INTRODUCTION}

Progressive multifocal leukoencephalopathy (PML) is a demyelinating disease that affects the central nervous system (CNS). It is caused by the John Cunningham virus (JCV), an ubiquitous human pathogen, that causes lytic infection of oligodendrocytes and consequent demyelination of white matter in immunosuppressed patients. ${ }^{1}$ With the advent of the Human Immunodeficiency Virus (HIV) pandemic, HIV infection became the most significant risk factor for PML, responsible in some series for up to $80 \%$ of all cases. ${ }^{2-4}$ Less commonly, PML can occur in other immunodeficiency settings such as hematologic malignancies (13\%), organ transplant recipients $(5 \%)$, and diseases treated with immunosuppressive drugs (3\%). ${ }^{5}$

PML lesions may be apparent both macroscopically and microscopically. Typically it occurs as a multifocal process but it may also be monofocal. Lesions may occur in any location in the white matter, with dimensions ranging from 1 millimeter to several centimeters. ${ }^{6}$ Larger lesions usually result from the coalescence of multiple smaller lesions. Very extensive demyelination can result in the involvement of an entire hemisphere and may lead to atrophy of the affected structures. $^{7}$

The most common symptoms are motor weakness, visual impairment and altered mental status, including cognitive abnormalities and behavior/personality change. Neurological signs are present in almost $80 \%$ of the patients, which is helpful in the distinction from HIV-associated encephalopathy. ${ }^{8}$ An inflammatory form of PML may occur after the introduction of antiretroviral therapy (ART) - the immune reconstitution inflammatory syndrome (IRIS) associated with JCV infection. It may present either as an exacerbation of established PML (i.e., 'paradoxical' IRIS) or as a first presentation of PML (i.e. 'unmasking' IRIS). ${ }^{9}$

Brain biopsy is the gold standard for the definite diagnosis of PML, allowing neuropathologic demonstration of the typical histopathologic triad of demyelination, bizarre astrocytes and enlarged oligodendroglial nuclei. ${ }^{6}$ Consensus statements have based the diagnosis of PML on clinical, imaging and laboratory data, allowing the avoidance the invasiveness and risks of brain biopsy. ${ }^{6}$ The course of the disease can be rapidly progressive, particularly in severe immunosuppressed patients. There is no specific treatment for PML other than commencing or optimizing ART, although an improved prognosis can be associated with immunological responsiveness. ${ }^{10}$ Median survival time has increased since the introduction of highly active anti-retroviral therapy (HAART), although important neurological sequelae are reported in surviving patients. ${ }^{11}$

The aim of this study is to evaluate the clinical and radiological features of $\mathrm{PML}$ in an HIV population, focusing on the different diagnostic tools available, particularly the advances in neuroimaging, possible therapeutic strategies, and prognosis.

\section{MATERIAL AND METHODS}

We performed a retrospective analysis of the clinical and radiological data of patients admitted to our institution from January 2005 to April 2014 with the diagnosis of 'definitive PML'6 (ICD10:A81.2). Diagnosis was based on demonstration of typical histopathologic findings in brain specimens with positive tissue PCR for JCV; or the combination of clinical, radiographic and laboratory data, particularly the presence of clinical and magnetic resonance (MR) imaging features consistent with the diagnosis, together with the demonstration of JCV by PCR in the cerebrospinal fluid (CSF). Patients with 'probable PML' or 'possible PML' were excluded from the study. ${ }^{6}$ We proceeded to the characterization of our sample, evaluating several parameters consisting of clinical features of $P M L$, laboratory data including CD4+ count, HIV viral load, JCV detection by polymerase chain reaction (PCR) in the $\mathrm{CSF}$, and radiological features such as lobar involvement, symmetry of lesions, pattern of proton diffusion, contrastenhancement and the presence or subsequent development of IRIS. The radiological characterization of the lesions was based on the evaluation of MR sequences performed at 1.5 or 3 Tesla using standard protocols for the evaluation of these patients in our institution: T1 spin-echo (SE), T2 turbo spin-echo (TSE), T2 fluid-attenuated inversion recovery (FLAIR) and diffusion-weighted imaging (DWI) in the axial plane, sagittal T2 turbo spin-echo (TSE) and post-contrast T1-weighted images both in the axial and coronal planes.

\section{RESULTS \\ Patient population}

Within the time period evaluated, 21 patients with HIV 
infection were diagnosed with 'definite PML', twenty of them $(95.2 \%)$ were men. Mean age at diagnosis was 39.1 years $(S D=7.7)$. Mean time since HIV diagnosis until PML diagnosis was 7.8 years $(S D=3.3)$. Fifteen patients $(71 \%)$ acquired HIV infection in the setting of intravenous drug use (IDU) and six patients (29\%) from sexual risk behavior. Seventeen patients $(81 \%)$ had history of previous acquired immune deficiency syndrome (AIDS)-related diseases, including esophageal candidiasis, tuberculosis, Pneumocystis jiroveci pneumonia and non-Hodgkin's lymphoma. Median CD4+ T-lymphocyte count was 44 cells/ $\mathrm{mm}^{3}$ (range 4 to 638 ) and fourteen $(66.7 \%$ ) patients had less than 100 cells $/ \mathrm{mm}^{3}$. All patients had clinical indication for ART; from the seven (33\%) patients that were under HIV treatment at PML diagnosis, two $(9.5 \%)$ had undetectable blood HIV viral load.

\section{Clinical features}

There were motor deficits (hemiparesis/hemiplegia) in $13(61.9 \%)$ patients, altered mental status including cognitive abnormalities in 10 (47.6\%); speech disturbances with dysarthria in 8 (38\%); impaired vision including homonymous hemianopia in $5(23.8 \%)$; ataxic gait in 3 (14.3\%); nystagmus in $2(9.5 \%)$; seizures in $2(9.5 \%)$; and lower limb paresthesia and dysmetria in one patient each $(4.7 \%)$. Detection of JCV-DNA by PCR in the CSF was positive in 20 patients. One patient with undetectable JCV-DNA in the CSF underwent brain biopsy, which demonstrated histopathologic findings suggestive of $\mathrm{PML}$ and tissue analysis was positive for the presence of the virus.

\section{Brain imaging}

Brain MRI depicted T2-hyperintense and T1-hypointense lesions considered typical of PML. Eleven (52.4\%) patients had an exclusively supratentorial involvement while in 4 $(14 \%)$ the lesions were located only in the infratentorial region; six $(28.6 \%)$ patients showed lesions in both compartments. Supratentorial lesions were unilateral in $41.1 \%$ of the cases and bilateral in $58.9 \%$. Bilateral supratentorial lesions were asymetric in all patients. Frontal lobe involvement was documented in 15 (71.4\%) patients and 16 patients $(76.1 \%)$ had lesions involving the parietal lobes. Temporal and occipital involvement was seen in 9 $(42.8 \%)$ patients. Diffusion-weighted imaging (DWI) was performed in all patients, showing restricted proton diffusion in the advancing edge of the lesion in 13 cases $(61.9 \%)$. Three $(14.3 \%)$ patients showed enhancement on postcontrast T1-weighted images.

\section{Follow-up}

Four (19\%) patients developed Immune Reconstitution Inflammatory Syndrome (IRIS) in the follow-up: three developed PML and IRIS simultaneously ('unmasking' IRIS) and in the other there was a worsening of preexisting $P M L$ after ART was started ('paradoxical' IRIS).

Therapeutic approach included initiation of ART in 9
(42.8\%) patients, continuation/optimization of ART in 6 (28.6\%), and adjunctive therapy with corticosteroids in 4 (19\%). In two patients (9.5\%) ART was suspended because of disease progression under treatment, manifested by worsening of clinical and MRI features.

Seventeen ( $81 \%$ ) patients died, and the median survival time after PML diagnosis was 3 months $(\min =1$ and $\max$ $=13)$. Four $(19 \%)$ patients survived, and their followup period ranged from 18 months to 6 years. The CD4+ lymphocyte count in these surviving patients varied from 27 to $301 \mathrm{cells} / \mathrm{mm}^{3}$ at the time of PML diagnosis. All surviving patients presented neurological sequelae including visual impairment, hemiparesis, gait abnormalities, dysmetria and myoclonic seizures. Table 1 summarizes these findings.

\section{DISCUSSION}

PML typically affects immunocompromised patients, although some reports have been published describing cases without any immunodeficiency. ${ }^{12-14}$

Currently, HIV infection is the condition most commonly associated with PML, particularly in severely immunosuppressed AIDS patients. In the pre-HAART era, PML affected $3 \%-7 \%$ of patients with HIV-1 infection and was the cause of up to $18 \%$ of fatal CNS disease. ${ }^{15}$ The incidence of PML has decreased from 0.7 per 100 person-years of follow-up in 1994 to 0.07 in $2001-2$ 002. ${ }^{16}$ Additionally, one-year survival rates in HIV patients with PML has increased from less than $30 \%$ in the preHAART era to $38 \%-62 \%$ with HAART. ${ }^{17}$ However, PML is still the second most common cause of all AIDS-related deaths $(14 \%)$, following non-Hodgkin lymphoma, carrying the most unfavorable prognosis of all AIDS-related brain conditions. ${ }^{18,19}$

PML usually develops in patients with CD4 $+<200$ cells/ $\mathrm{mm}^{3}$ and can occur in patients receiving ART. ${ }^{20}$ In our case series the majority of the patients had history of AIDS-related diseases $(81 \%)$ and were severely immunosuppressed $\left(66.7 \%\right.$ with CD4+ < 100 cells $\left./ \mathrm{mm}^{3}\right)$, and $33 \%$ were under ART at the time of PML diagnosis.

Virtually any area of the brain may be involved, so the clinical manifestations can be quite diverse. Some variation in the frequency of clinical features may be related to the underlying predisposing cause of PML. Motor weakness has been shown to be a feature in more than one-half of the patients with AIDS-related PML. ${ }^{21,22}$ Accordingly, we found motor deficits to be the most frequent neurological deficit in this series, seen in $61.9 \%$ of patients. Although clinical features related to cerebral hemisphere lesions are the most common symptoms, brainstem and cerebellar involvement can also occur, leading to ataxia, dysmetria, dysarthria, and oculomotor nerve palsies. Other signs and symptoms associated with PML include headache, vertigo, seizures, sensory deficits, parkinsonism, aphasia, and neglect syndromes. ${ }^{21,23}$ In our series, those findings were also documented, including ataxic gait $(14.3 \%)$, seizures $(9.5 \%)$ and dysmetria (4.7\%). Meningitis and encephalopathy are rare manifestations of this disease,,$^{24,25}$ and isolated spinal 
cord involvement is even less common.

Early PML diagnosis is important due to recent expansion of people at risk for JCV infection and because it is believed that the detection of the disease before the onset of clinical symptoms leads to a better prognosis. This relationship is difficult to establish in HIV patients, as there are other conditions that usually influence the prognosis, but it has been proven in non-HIV patients, particularly natalizumab-associated PML cases. ${ }^{26}$

Brain biopsy with histopathologic examination is the standard diagnostic procedure, with a sensitivity and specificity of $64 \%-96 \%$ and $100 \%$, respectively, ${ }^{27}$ and estimated rates of complications and morbidity of $2.9 \%$ and $8.4 \% .{ }^{28}$ However, brain biopsy should be avoided whenever possible, due to its invasiveness. Patients may be very debilitated or even unwilling to undergo this procedure and lesion location may become a caveat. In these cases the diagnosis must be established with clinical and imaging criteria along with the demonstration of the virus in the CSF using PCR. ${ }^{6,11}$ Before the introduction of HAART, PCR for JCV-DNA was $72 \%-92 \%$ sensitive and $92 \%-100 \%$ specific for the diagnosis of PML. ${ }^{8}$ Recently, however, it has become common to have negative CSF molecular results in patients with AIDS with clinical and imaging presentations indistinguishable from those of PML. This may be due to the immune restoration with antiretroviral therapy leading to a decreased viral replication and increased clearance of JCVDNA from the CSF. ${ }^{29}$ As a result of this, the sensitivity of PCR testing for JCV-DNA is now estimated to be around $58 \%{ }^{30,31}$ Berger et al. 2013 have also proposed that PML diagnosis should be considered 'possible' when there is evidence of typical imaging and clinical findings with no documentation of JCV either in brain biopsy or in the CSF. ${ }^{6}$ In our series, detection of JCV-DNA by PCR in CSF was positive in 20 patients (95\%). One patient had undetectable JCV-DNA in CSF and, in order to achieve diagnosis, a brain biopsy was performed, demonstrating suggestive histopathologic findings of PML and detecting JCV-DNA by PCR in brain tissue. The high proportion of positive molecular test results of JCV-DNA in CSF could be explained by the diagnostic criteria used in our study.

PML can also occur in the setting of immunosupressive therapies, particularly treatment of multiple sclerosis (MS) with natalizumab (Tysabri®, Biogen Idec Inc, Cambridge, Massachusetts, USA), a selective adhesion molecule inhibitor that blocks a4 integrin, a molecule expressed on the surface of lymphocytes acting on endothelial adhesion and facilitating migration of peripheral blood lymphocytes into the central nervous system through the blood-brain barrier (BBB). ${ }^{32}$ Studies have demonstrated consistent efficacy in the treatment of patients with relapsingremitting multiple sclerosis (RRMS) with natalizumab, significantly decreasing annual relapse rate by $68 \%$ and sustained disability progression by $54 \%$, and also the appearance of new lesions on MRI scans. ${ }^{33,34}$ However, this immunomodulating effect is associated with an increased risk of PML lesions, depending on the duration of exposure to the drug, anti-JCV antibody serology status, and prior or current administration of immunosuppressive therapies..$^{35-37}$ In April 2014, there were 454 cases of natalizumabassociated PML documented in more than 123000 treated patients with an overall survival rate of $77 \% .^{38}$ Indeed, an adequate and frequent clinical monitoring, including serological tests and radiological evaluation, are of extreme importance in the follow-up of these patients in order to prevent and enable early detection of PML lesions. ${ }^{39-41} \mathrm{At}$ our center there is only 1 patient diagnosed with $\mathrm{PML}$ in the context of MS treatment with natalizumab. Considering this, we believe that any results obtained evaluating nonHIV PML patients would lack significance and we decided to focus our work only on patients with HIV-associated PML.

\section{Brain images}

MR imaging is the technique of choice for assessing PML. ${ }^{5}$ Typically, PML is a confluent, bilateral but asymmetric, supratentorial white matter disease. ${ }^{8,42}$ However, it can be unilateral, infratentorial, and there may be a single lesion. Lesions are usually hypointense on T1-weighted images (T1WI) and hyperintense on T2-weighted images (T2WI) involving the subcortical u-fibers and usually sparing the cortex and deep gray matter structures (Fig. 1). ${ }^{43}$ The parietal lobe is described as the most commonly involved, followed by the frontal lobe. Similar findings were found in our series.

Supratentorial lesions typically involve subcortical white matter with a scalloped appearance. ${ }^{44}$ This involvement has been reported to progress from the subcortical regions - the site of highest blood flow - into the deeper white matter in the centrum semiovale and periventricular regions. ${ }^{45}$ Other regions, such as the internal capsule, the external capsule, and the corpus callosum are less commonly involved. White matter of the posterior fossa can also be involved, with the middle cerebellar peduncle, the adjacent pons and cerebellum being the most frequently affected sites..$^{5,42}$ Pontine lesions may extend to the midbrain. Spinal cord involvement in PML is exceedingly rare, with only a few autopsy reports revealing involvement of this structure by the JC virus. ${ }^{46}$ There are no documented reports of spinal cord PML imaging. ${ }^{5}$ Although less frequently, deep gray matter structures may be involved, usually in the setting of an expanding white matter lesion, as the unique involvement of deep gray matter structures is very rare. ${ }^{47}$

The hypointense signal on T1, asymmetry and subcortical involvement seen in PML lesions, allows differential diagnosis with HIV encephalopathy. ${ }^{5}$ With the initiation of HAART and with disease progression, T1 signal intensity has been shown to drop even further. ${ }^{5,44}$ In some of the PML lesions, there may be an incomplete hyperintense rim on precontrast $\mathrm{T} 1$-weighted sequences at the advancing edge. This feature is not fully understood but may be related to the presence of foamy (lipid laden) macrophages, in response to myelin breakdown. ${ }^{11}$ As there is little or no inflammation associated, there is no breach of blood-brain barrier, so typically there is no lesion contrast enhancement. 


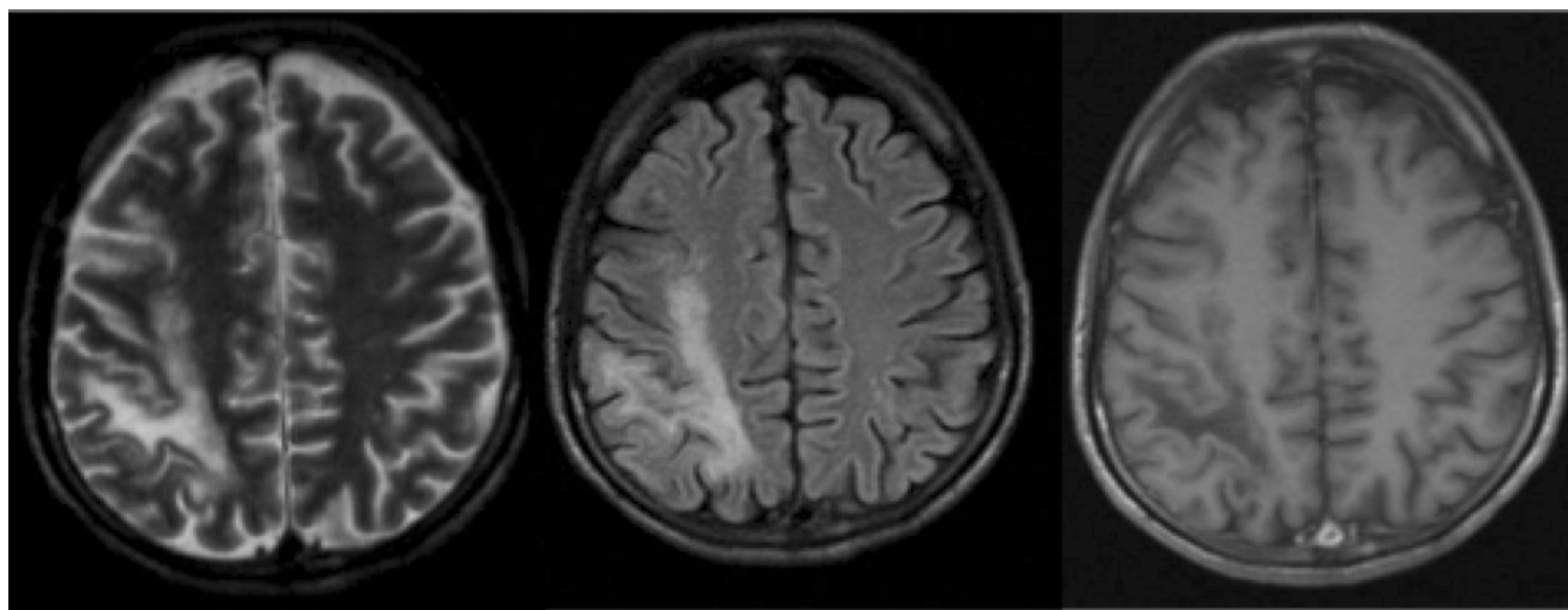

Figure 1 - Brain MRI in the axial plane depicting a hyperintense right frontoparietal lesion on both T2-turbo-spin-echo (left) and T2 Fluid Attenuated Inversion Recovery (FLAIR) (center) involving the subcortical u-fibers and sparing the cortex with no significant mass effect. Note also the absence of contrast enhancement in T1 spin-echo images (right), typical of PML.

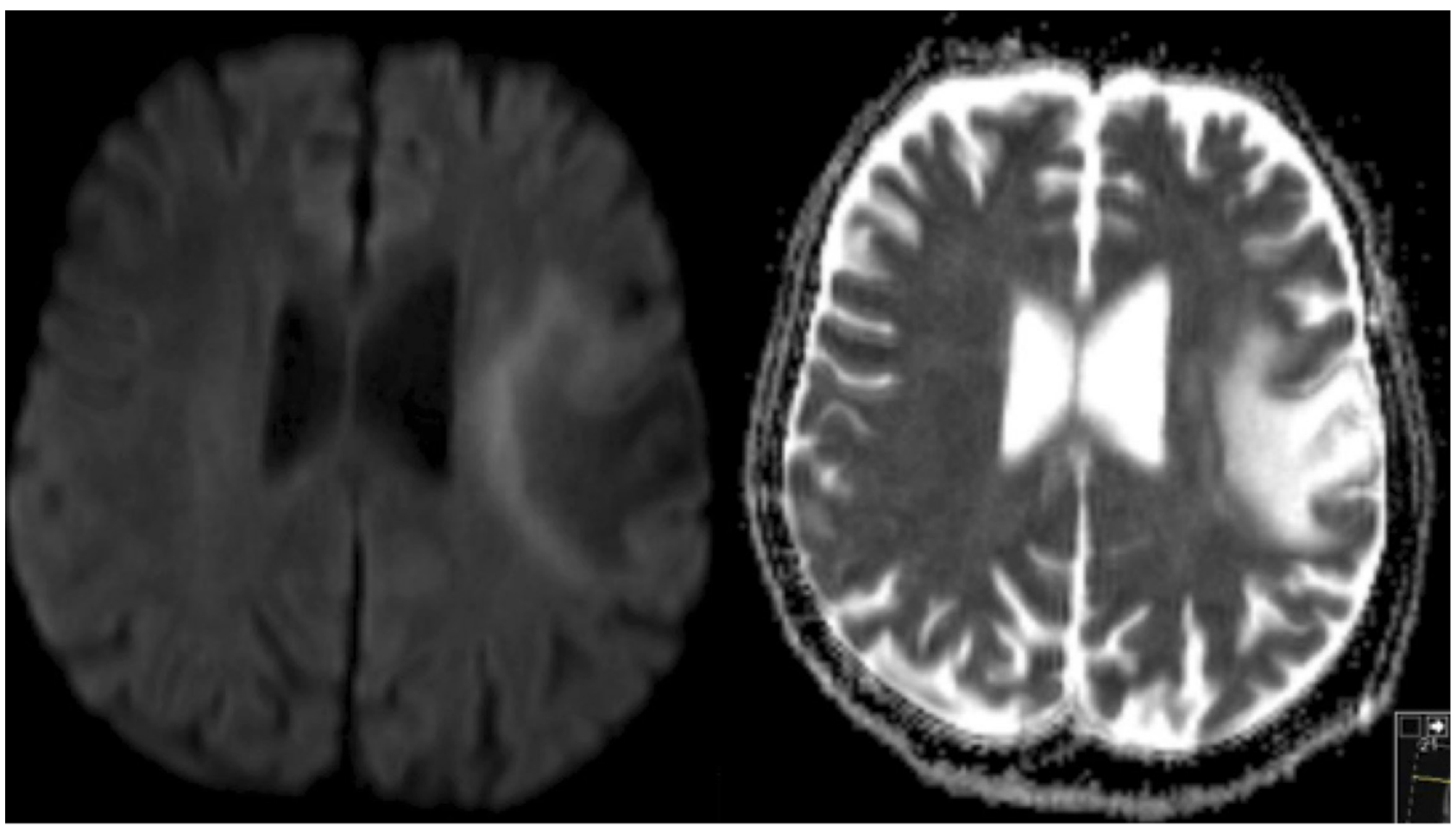

Figure 2 - Brain MRI. Axial diffusion weighted imaging (DWI; $b=1000)$ (left) and apparent diffusion coeficient (ADC) (right) showing peripheral restricted diffusion in a lesion involving both the frontal and parietal lobes on the left brain hemisphere.

Another typical imaging finding is the absence of atrophy in the active stage. However, it is worth noticing that this lesion pattern may be somewhat different in non-HIV associated PML since those lesions may extend to the cortical graymatter and contrast-enhancement can be seen in $30-40 \%$ of the patients in the early stages of PML lesions associated to natalizumab treatment for MS. ${ }^{48,49}$ More recently, other JCV-associated disease entities have been described in which lytic infection predominately occurs in grey matter cells. Amongst these, Granule Cell Neuropathy (GCN) is characterized by a selective infection of the granule cell neurons in the cerebellum, leading to neuronal loss and gliosis and cerebellar atrophy, which is the most consistent
MRI finding in these patients. Cerebellar white matter lesions may also be present, which suggests that GCN and PML may coexist. ${ }^{50}$ However, in our series, all atrophic changes affected both the supratentorial and infratentorial compartments and we found no evidence of changes that could suggest the diagnosis of GCN.

The appearance on diffusion-weighted imaging (DWI) varies according to the disease stage. ${ }^{51} \mathrm{New}$ active lesions show a rim of restricted diffusion at the advancing edge and a central core of facilitated diffusion (Fig. 2). This rim is usually incomplete and is a sign of active infection. ${ }^{11}$ Histopathologically, this advancing edge correlates with large swollen oligodendrocytes, enlarged 'bizarre 
astrocytes' with numerous large processes, and infiltration of foamy macrophages. This cellular enlargement reduces the extracellular space, impairing the maximum Brownian motion of water. Restricted diffusion can either be due to constricted extracellular space or enlarged cells per se due to entrapment of water in motion-restricted intracellular space. ${ }^{5}$ In older lesions, after therapy or at the center of a large lesion, facilitated diffusion is due to disorganized cellular architecture, increased extracellular space secondary to the death of oligodendrocytes, macrophage action, and astrocytic reparative responses. ${ }^{51}$

Diffusion tensor imaging (DTI) also has an important role in the evaluation of PML lesions. Fractional anisotropy (FA) - reflecting the organized architecture of the white matter - decreases in PML, suggesting disorganization of the white matter structure. In fact, FA values may decrease in earlier stages of the disease, when no lesion is evident on conventional and DWI sequences. ${ }^{52} \mathrm{DTI}$ parameters have also shown disorganized cellular architecture at the center of a large confluent lesion. ${ }^{53}$

In proton MR spectroscopy (MRS) studies, in the early stage of HIV infection, the $\mathrm{N}$-acetylaspartate/Creatine (NAA/Cr) ratio is unchanged $(92 \%-98 \%$ of normal value). With the development of the AIDS complex, NAA/Cr decreases $\left(62 \%-84 \%\right.$ of normal value). ${ }^{54,55}$ The metabolic abnormalities increase proportionally with the severity of the disease. ${ }^{56}$ In PML, there is a substantial decrease of the NAA peak to the contralateral NAA value, whether measured in relation to creatine or by absolute quantification, which probably means neuronal loss. The choline peak is elevated, perhaps reflecting myelin destruction. ${ }^{57}$ The mlns (myoinositol) peak may be normal or significantly elevated compared with the contralateral normal-appearing white matter. The level of mins depends on disease stage. In early and active stages, its level is increased, gradually decreasing to normal levels seen in late quiescent stages. ${ }^{58}$ Elevation of the $\mathrm{mlns} / \mathrm{Cr}$ ratio, in relation to local glial proliferation secondary to inflammation, has recently been described as a prognostic marker of the disease. In acute lesions, a significantly increased $\mathrm{m} / \mathrm{ns} / \mathrm{Cr}$ ratio is associated with increased survival time probably due to more intense inflammation that hinders PML disease progression. ${ }^{59}$ With this explanation, it is possible that the mins peak may also be elevated in PML-IRIS because of the associated intense inflammation.

\section{IRIS}

CNS-immune reconstitution syndrome (IRIS) defines a paradoxical deterioration of clinical response, mostly encountered in HIV-infected patients who have received HAART, ${ }^{60}$ although it may also be developed in patients with immunological deficits related to other conditions. It represents a diagnostic challenge, with limited treatment options and variable prognosis. ${ }^{61}$ The diagnosis of IRIS must be suspected when clinical symptoms are more consistent with an inflammatory process rather than an expected course of an opportunistic infection or drug toxicity. In the setting of HIV infection, risk is higher for antiretroviral naïve patients, but it is also related to the duration and extent of immunodeficiency, polymorphisms in cytokine genes, high initial viral load and rate of immune reconstitution. ${ }^{5,62,63}$

IRIS is often dominated by CD8+ T-lymphocyte inflammatory infiltrates with JCV being the most common inciting agent in the CNS. ${ }^{24,64}$ Less common IRISassociated pathogens are Cryptococcus spp., herpes virus and cytomegalovirus. ${ }^{65,66}$ Rarely, autoimmune diseases and tumors may also cause IRIS. ${ }^{65}$

PML-IRIS is reported to occur in $18-45 \%$ of the HIV-

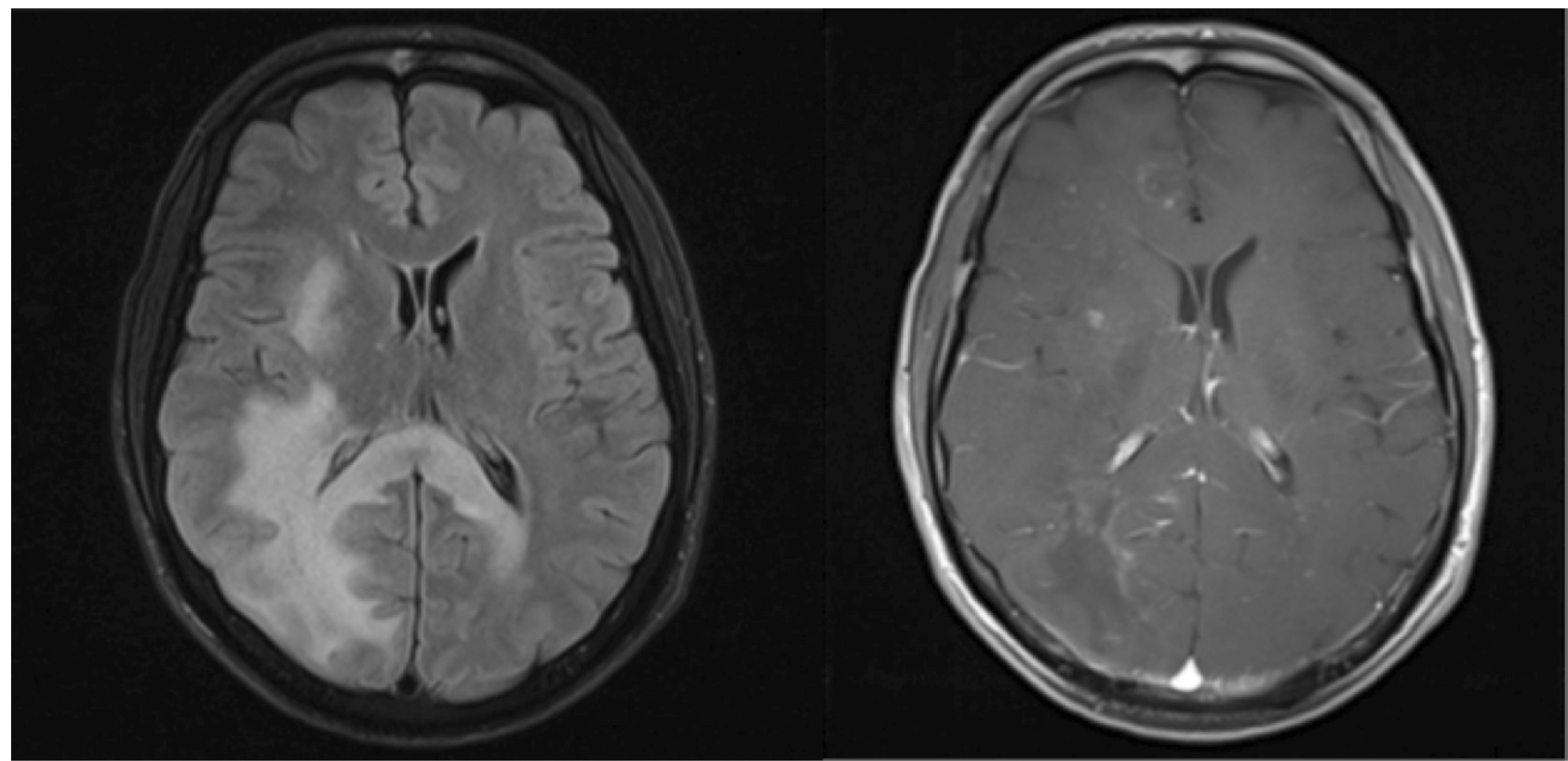

Figure 3 - Axial brain MRI showing a T2 FLAIR hyperintense right fronto-parietal lesion (left) extending to the contralateral side through the splenium of the corpus callosum with mass effect and patchy enhancement on post-contrast T1-weighted images (right), in a patient diagnosed with CNS-Immune Reconstitution Syndrome (IRIS). 
infected patients with PML.66,67 As noted previously, PML and IRIS may develop simultaneously in neurologically healthy patients with the start of HAART ('unmasking' IRIS) or there may be worsening neurologic symptoms in patients with previously manifested PML due to development of IRIS following initiation of HAART ('paradoxical' IRIS). ${ }^{68}$ In this study, four (19\%) patients developed IRIS: three patients developed PML and IRIS simultaneously ('unmasking' IRIS) and in one worsening of preexisting PML occurred after ART was started ('paradoxical' IRIS). In all these patients with IRIS, adjunctive therapy with corticosteroids was started and two of them survived.

Most PML-IRIS cases are characterized by mild symptoms and limited CNS inflammation. Unlike PML, brain MR imaging in IRIS patients depicts lesion enhancement on post-contrast T1-weighted sequences (Fig. 3) in 56-86\% of patients, with associated edema and mass effect. ${ }^{69-72}$ Nonetheless, non-enhancement of a PML lesion with clinical deterioration does not preclude the diagnosis. To date, there is no biomarker that confirms IRIS. PML-IRIS may have a more favorable outcome if treated appropriately with steroids. ${ }^{69}$

\section{Treatment}

There is no specific therapy for PML, although a positive response may occur following the improvement of the immunological status. ${ }^{29}$ HAART is the only intervention proven to improve clinical outcomes in HIV patients with PML. ${ }^{73,74}$ The therapeutic approach may include starting ART in patients without treatment, or optimization of previous ART regimens. In IRIS cases, adjunctive therapy with corticosteroids is commonly used. However the effectiveness of this approach is not proven and it may limit JCV viral clearance. ${ }^{75,76}$ More recently, it has been reported the use of CCR5 antagonist maraviroc in patients with multiple sclerosis and PML with high risk of IRIS, wherein maraviroc was associated with a selective decrease in CCR5+ CSF cells, with good clinical results in prevention and active treatment of PML-associated IRIS, without the use of glucocorticoids. ${ }^{75}$ These results suggest that maraviroc may selectively limit immune-cell chemotaxis into the CNS and highlights its potential use for the management of PML-IRIS.

In our study, ART was started in $43 \%$ of patients, maintained or optimized in $29 \%$ and was suspended in 2 patients because of disease progression under treatment manifested by worsening of clinical and radiological features.

\section{Prognosis}

Until recently, PML was regarded as virtually fatal. The average survival in the pre-AIDS era was approximately 6 months, and mortality was $80 \%$ within 9 months of disease onset. ${ }^{21}$ In the early years of the AIDS era, survival with PML did not appear to differ significantly from that observed in the pre-AIDS years. In the largest study of HIV associated $\mathrm{PML}$ in the pre-HAART era, median survival was 183 days.
However, the majority of individuals died within 3 months of diagnosis and only $8 \%$ to $10 \%$ of patients survived longer than 12 months. ${ }^{77}$

Most studies show that the incidence of HIV-associated PML has declined and the prognosis of affected patients has improved after the introduction of HAART. One-year survival rates in HIV patients with $\mathrm{PML}$ increased from less than $30 \%$ in the pre-HAART era to $38 \%-62 \%$ with HAART. ${ }^{17}$ This highlights the importance of restoring the immune system for both disease prevention and survival. Nonetheless, PML continues to have the worst prognosis of any AIDS-related cerebral disorder and it is still the second most common cause of all AIDS-related deaths (14\%), following non-Hodgkin lymphoma, with those having advanced immunosuppression being the most susceptible. ${ }^{18,19}$ During follow-up, in our series, $81 \%$ of the patients progressed to death within 1 to 13 months after PML diagnosis, with a median survival time following diagnosis of 3 months. The high mortality found in this study is in line with the well-recognized poor outcome of PML and the severe immunosuppression found in our patients, since the majority had very low CD4+ lymphocyte counts, history of AIDS-related diseases, and no ART at the time of diagnosis despite clinical indication.

Several factors related with an improved outcome of PML have been described in literature. Better survival has been correlated with higher CD4+ cell counts at disease onset, immunological responsiveness, particularly an improvement in CD4 lymphocyte counts (CD4 counts > 100 cells $/ \mathrm{mm}^{3}$ ), and reduced JCV load in the CSF. ${ }^{78,79}$ We were unable to perform the quantification of JCV viral load, however this could be important since a high JCV load with delayed clearance is associated with poorer prognosis. ${ }^{74}$ For AIDS patients with PML, those who were HAART-naïve at the time of diagnosis appear to have better survival than treatmentexperienced patients; ${ }^{19}$ in our series we did not find this in the seven patients under ART at PML diagnosis. Other factors such as contrast enhancement on brain imaging studies, perivascular mononuclear infiltrates in PML lesions and absence of brain stem involvement are associated with longer survival. ${ }^{10}$ In this study four patients (19\%) survived, with a follow-up period ranging from 18 months to 6 years. Three of these four surviving patients were already under ART and the previous regimen was maintained. The CD4+ lymphocyte count at the time of diagnosis in the surviving patients was variable from severe immunosuppression in one patient (with 27 cells $/ \mathrm{mm}^{3}$ ) to higher CD4+ counts (Table 1), but the low number of patients does not allow to establish a correlation between CD4+ count and survival in this study. All surviving patients experienced immunological reconstitution afterwards. Although median survival time has increased since HAART, important neurological sequelae are reported in surviving patients and in our study the four surviving patients presented neurological sequelae including visual impairment, hemiparesis, gait abnormalities, dysmetria and myoclonic seizures. 
Table 1 - Clinical, laboratory and imaging findings in PML patients (continues)

\begin{tabular}{|c|c|c|c|c|c|c|}
\hline Gender & $\begin{array}{l}\text { Age at PML } \\
\text { diagnosis }(y)\end{array}$ & Clinical Presentation & $\begin{array}{l}\text { CD4+ count } \\
\left(\text { cells } / \mathrm{mm}^{3}\right)\end{array}$ & JCV & $\begin{array}{l}\text { Brain } \\
\text { biopsy }\end{array}$ & $\begin{array}{c}\text { Right hemisphere } \\
\text { lesions }\end{array}$ \\
\hline M & 48 & Seizures, motor deficit & 33 & Pos & No & $\mathrm{F}+\mathrm{P}+\mathrm{T}$ \\
\hline M & 34 & Cognitive impairment & 15 & Pos & No & $\mathrm{P}+\mathrm{T}$ \\
\hline M & 35 & Motor deficit & 44 & Pos & No & --- \\
\hline M & 32 & Motor deficit & 85 & Pos & No & $\mathrm{F}$ \\
\hline M & 49 & Motor deficit & 638 & Pos & No & $\mathrm{F}+\mathrm{P}+\mathrm{T}$ \\
\hline$M$ & 37 & Seizures, motor deficit & 24 & Pos & No & $\mathrm{F}+\mathrm{P}+\mathrm{O}+\mathrm{T}$ \\
\hline$M$ & 50 & Cognitive impairment & 66 & Pos & No & --- \\
\hline M & 49 & Motor deficit & 246 & Pos & No & $\mathrm{F}+\mathrm{P}$ \\
\hline M & 44 & Dysarthria e paresthesias & 5 & Pos & $\begin{array}{l}\text { Positive } \\
\text { (autopsy) }\end{array}$ & --- \\
\hline M & 40 & Cognitive impairment & 27 & Pos & No & --- \\
\hline M & 30 & $\begin{array}{l}\text { Ataxic gait, cognitive } \\
\text { impairment }\end{array}$ & 158 & Pos & No & $\mathrm{T}+\mathrm{O}$ \\
\hline$M$ & 38 & $\begin{array}{c}\text { Dysarthria, nystagmus, } \\
\text { ataxic gait }\end{array}$ & 223 & Pos & No & --- \\
\hline M & 37 & Dysarthria, motor deficit & 20 & Pos & No & --- \\
\hline$M$ & 39 & $\begin{array}{l}\text { Cognitive impairment, } \\
\text { motor deficit }\end{array}$ & 42 & Pos & No & $\mathrm{F}+\mathrm{P}$ \\
\hline M & 29 & Cognitive impairment & 4 & Pos & No & $\mathrm{F}+\mathrm{P}$ \\
\hline M & 34 & Dysarthria, motor deficit & 54 & Pos & No & --- \\
\hline $\mathrm{F}$ & 37 & Visual and motor deficit & 4 & Pos & No & $\mathrm{F}+\mathrm{P}+\mathrm{O}+\mathrm{T}$ \\
\hline$M$ & 53 & Ataxic gait, nystagmus & 197 & Pos & No & --- \\
\hline M & 39 & Motor deficit & 237 & Neg & Positive & $\mathrm{F}+\mathrm{P}$ \\
\hline$M$ & 43 & Cognitive impairment & 301 & Pos & No & $\mathrm{P}+\mathrm{O}+\mathrm{T}$ \\
\hline$M$ & 23 & $\begin{array}{l}\text { Visual deficit and } \\
\text { cognitive impairment }\end{array}$ & 27 & Pos & No & $\mathrm{P}$ \\
\hline
\end{tabular}

JCV - John Cunningham Virus; IRIS - Immune Reconstitution Inflammatory Syndrome; F - Frontal; O - Occipital; P - Parietal; T - Temporal lobes.

\section{CONCLUSION}

The purpose of this study was to evaluate and review the clinical and neuroimaging characteristics of patients with PML in the context of HIV infection, during a 10-year period. The results obtained were in line with those described in the literature. The majority of patients in this series had prior AIDS diagnosis, presented a severe immunosuppression at the time of PML diagnosis and was not under HIV treatment despite clinical indication for ART.

This study also highlights the increasing role of MRI in the diagnosis of PML and other differential diagnosis, since brain biopsy is not a feasible procedure in a high number of cases and considering the low sensitivity of JC DNA detection in CSF. As there are multiple possible entities that can mimic PML, we decided to limit the inclusion criteria to patients with "definite PML". This decision may have reduced the number of patients included, but it is our belief that it has led to more accurate findings.

Despite the therapeutic approaches undergone, the mortality in this study was high (81\%), with a low median 
Table 1 - Clinical, laboratory and imaging findings in PML patients (final)

\begin{tabular}{|c|c|c|c|c|c|c|}
\hline Gender & $\begin{array}{l}\text { Left hemisphere } \\
\text { lesions }\end{array}$ & $\begin{array}{c}\text { Posterior } \\
\text { fossa lesions }\end{array}$ & $\begin{array}{c}\text { Restricted } \\
\text { diffusion on DWI }\end{array}$ & Enhancement & IRIS & Death \\
\hline$M$ & $\mathrm{~F}+\mathrm{P}$ & No & No & No & No & Yes \\
\hline$M$ & $\mathrm{~F}+\mathrm{P}+\mathrm{T}+\mathrm{O}$ & No & No & No & No & Yes \\
\hline$M$ & $\mathrm{~F}$ & Yes & Yes & No & No & Yes \\
\hline$M$ & $\mathrm{~F}+\mathrm{P}$ & Yes & Yes & No & No & Yes \\
\hline$M$ & $\mathrm{~F}+\mathrm{O}+\mathrm{T}$ & No & Yes & No & No & Yes \\
\hline$M$ & -- & No & Yes & Yes & Yes & Yes \\
\hline$M$ & $\mathrm{~F}+\mathrm{P}+\mathrm{O}+\mathrm{T}$ & No & No & No & No & Yes \\
\hline$M$ & --- & Yes & Yes & No & No & Yes \\
\hline$M$ & --- & Yes & No & No & No & Yes \\
\hline$M$ & --- & Yes & Yes & No & No & Yes \\
\hline M & $\mathrm{P}+\mathrm{O}+\mathrm{T}$ & Yes & Yes & No & No & Yes \\
\hline M & --- & Yes & No & No & No & Yes \\
\hline$M$ & $\mathrm{~F}+\mathrm{P}$ & No & Yes & No & No & Yes \\
\hline$M$ & $\mathrm{~F}$ & No & No & No & No & Yes \\
\hline$M$ & --- & No & No & No & No & yes \\
\hline$M$ & --- & Yes & No & Yes & Yes & Yes \\
\hline $\mathrm{F}$ & $\mathrm{P}+\mathrm{O}$ & No & Yes & No & No & Yes \\
\hline$M$ & $\mathrm{~F}+\mathrm{P}+\mathrm{O}$ & Yes & Yes & No & No & No \\
\hline$M$ & $\mathrm{~F}$ & Yes & Yes & No & No & No \\
\hline$M$ & $P$ & No & Yes & Yes & Yes & No \\
\hline $\mathrm{M}$ & $\mathrm{F}+\mathrm{P}+\mathrm{O}+\mathrm{T}$ & No & Yes & No & No & No \\
\hline
\end{tabular}

JCV - John Cunningham Virus; IRIS - Immune Reconstitution Inflammatory Syndrome; F - Frontal; O - Occipital; P - Parietal; T - Temporal lobes.

survival time following PML diagnosis of 3 months. Among the patients who survived, all presented long-term neurological sequelae.

These data should increase clinician awareness to the occurrence of PML among HIV patients, in particular those with severe immunosuppression, who presented with focal neurological signs and suggestive findings on brain MRI, since PML still has one of the poorest outcomes in the HAART era among HIV-associated disorders. Better therapeutic strategies and etiologic therapy are urgently needed.

\section{PEOPLE AND ANIMALS PROTECTION}

The authors declare that the procedures were followed according to the regulations established by the Clinical Research and Ethics Committee and to the Helsinki Declaration of the World Medical Association.

\section{CONFIDENTIALITY OF DATA}

The authors declare having followed the protocols in use at their working center regarding patient's data publication. 


\section{CONFLICTS OF INTEREST}

The authors declare that there are no conflicts of interest.

\section{REFERENCES}

1. Tyler KL. Emerging viral infections of the central nervous system: part 2. Arch Neurol. 2009;66:1065-74.

2. Koralnik IJ. Progressive multifocal leukoencephalopathy revisited: has the disease outgrown its name? Ann Neurol. 2006;60:162-73.

3. Berger JR. Progressive multifocal leukoencephalopathy. Curr Neurol Neurosci Rep. 2007;7:461-9.

4. Weber T. Progressive multifocal leukoencephalopathy. Neurol Clin. 2008;26:833-54

5. Bag AK, Curé JK, Chapman PR, Roberson GH, Shah R. JC virus infection of the brain. AJNR Am J Neuroradiol. 2010;31:1564-76.

6. Berger JR, Aksamit AJ, Clifford DB, Davis L, Koralnik IJ, Sejvar JJ, et al. PML diagnostic criteria: consensus statement from the AAN Neuroinfectious Disease Section. Neurology. 2013;80:1430-8.

7. Richardson EP Jr, Webster HD. Progressive multifocal leukoencephalopathy: its pathological features. Prog Clin Biol Res. 1983;105:191-203.

8. Whiteman ML, Post MJ, Berger JR, Tate LG, Bell MD, Limonte LP. Progressive multifocal leukoencephalopathy in 47 HIV-seropositive patients: neuroimaging with clinical and pathologic correlation. Radiology. 1993;187:233-40.

9. French MA. Immune reconstitution inflammatory syndrome: a reappraisal. Clin Infect Dis. 2009;48:101-7.

10. Berger JR, Levy RM, Flomenhoft D, Dobbs M. Predictive factors for prolonged survival in acquired immunodeficiency syndrome-associated progressive multifocal leukoencephalopathy. Ann Neurol. 1998;44:341-

11. Cinque P, Koralnik IJ, Gerevini S, Miro JM, Price RW. Progressive multifocal leukoencephalopathy complicating HIV-1 infection. Lancet Infect Dis. 2009;9:625-36.

12. Johansen KK, Torp SH, Rydland J, Aasly JO. Progressive multifocal leukoencephalopathy in an immunocompetent patient? Case Rep Neurol. 2013;5:149-54

13. Christakis PG, Okin D, Huttner AJ, Baehring JM. Progressive multifocal leukoencephalopathy in an immunocompetent patient. J Neurol Sci. 2013;326:107-10.

14. Naess H, Glad S, Storstein A, Rinaldo $\mathrm{CH}$, Mørk SJ, Myhr KM, et al. Progressive multifocal leucoencephalopathy in an immunocompetent patient with favourable outcome. A case report. BMC Neurol. 2010;10:32.

15. Lang W, Miklossy J, Deruaz JP, Pizzolato GP, Probst A, Schaffner T, et al. Neuropathology of the acquired immune deficiency syndrome (AIDS): a report of 135 consecutive autopsy cases from Switzerland. Acta Neuropathol. 1989;77:379-90.

16. Cinque $P$, Vago L, Dahl $H$, Brytting M, Terreni MR, Fornara $C$, et al. Polymerase chain reaction on cerebrospinal fluid for diagnosis of virusassociated opportunistic diseases of the central nervous system in HIVinfected patients. AIDS. 1996;9:951-8.

17. Antiretroviral Therapy Cohort Collaboration (ART-CC), Mocroft A, Sterne JA, Egger M, May M, Grabar S, et al. Variable impact on mortality of AIDS-defining events diagnosed during combination antiretroviral therapy: not all AIDS-defining conditions are created equal. Clin Infect Dis. 2009;48:1138-51.

18. Lewden C, May T, Rosenthal E, Burty C, Bonnet F, Costagliola D, et al. Changes in causes of death among adults infected by HIV between 2000 and 2005: the "Mortalite 2000 and 2005" surveys (ANRS EN19 and Mortavic). J Acquir Immune Defic Syndr. 2008;48:590-8.

19. Wyen C, Hoffmann C, Schmeisser N, Wöhrmann A, Qurishi N, Rockstroh $\mathrm{J}$, et al. Progressive multifocal leukencephalopathy in patients on highly active antiretroviral therapy: survival and risk factors of death. J Acquir Immune Defic Syndr. 2004;37:1263-8.

20. Falcó V, Olmo M, del Saz SV, Guelar A, Santos JR, Gutiérrez M, et al. Influence of HAART on the clinical course of HIV-1-infected patients with progressive multifocal leukoencephalopathy: results of an observational multicenter study. J Acquir Immune Defic Syndr. 2008;49:26-31.

21. Berger JR. The clinical features of PML. Cleve Clin J Med. 2011;78:S812.

22. Clifford DB, DeLuca. A, Simpson DM, Arendt G, Giovannoni G, Nath A. Natalizumab-associated progressive multifocal leukoencephalopathy in patients with multiple sclerosis: lessons from 28 cases. Lancet Neurol. 2010;9:438-46

\section{FUNDING SOURCES}

No subsidies or grants contributed to this work.

23. Lima MA, Drislane FW, Koralnik IJ. Seizures and their outcome in progressive multifocal leukoencephalopathy. Neurology. 2006;66:262-4.

24. Blake K, Pillay D, Knowles W, Brown DW, Griffiths PD, Taylor B. JC virus associated meningoencephalitis in an immunocompetent girl. Arch Dis Child. 1992;67:956-7.

25. Wüthrich C, Dang X, Westmoreland S, McKay J, Maheshwari A, Anderson MP, et al. Fulminant JC virus encephalopathy with productive infection of cortical pyramidal neurons. Ann Neurol. 2009;65:742-8.

26. Dong-Si T, Richman S, Wattjes MP, Wenten M, Gheuens S, Philip J et al. Outcome and survival of asymptomatic PML in natalizumab-treated MS patients. Ann Clin TransI Neurol. 2014;1:755-64.

27. Koralnik IJ, Boden D, Mai VX, Lord Cl, Letvin NL. JC virus DNA load in patients with and without progressive multifocal leukoencephalopathy. Neurology. 1999;52:253-60.

28. Skolasky RL, Dal Pan G, Olivi A, Lenz FA, Abrams RA, McArthur JC. HIV-associated primary CNS morbidity and utility of brain biopsy. J Neurol Sci. 1999;163:32-8

29. Cinque P, Bossolasco S, Brambilla AM, Boschini A, Mussini C, Pierotti $C$, et al. The effect of highly active antiretroviral therapy-induced immune reconstitution on development and outcome of progressive multifocal leukoencephalopathy: study of 43 cases with review of the literature. Neurovirol. 2003;9:S73-80

30. Antinori A, Cingolani A, Lorenzini P, Giancola ML, Uccella I, Bossolasco $S$, et al. Clinical epidemiology and survival of progressive multifocal leukoencephalopathy in the era of highly active antiretroviral therapy: data from the Italian Registry Investigative Neuro AIDS (IRINA). J Neurovirol. 2003;9:S47-53.

31. Marzocchetti A, Di Gianbenedetto S, Cingolani A, Ammassari A, Cauda $R$, De Luca A. Reduced rate of diagnostic positive detection of JC virus DNA in cerebrospinal fluid in cases of suspected progressive multifocal leukoencephalopathy in the era of potent antiretroviral therapy. $\mathrm{J}$ Clin Microbiol. 2005;43:4175-7.

32. Rudick RA, Uma Sandrock. Natalizumab: alpha 4-integrin antagonist selective adhesion molecule inhibitors for MS. Expert Rev Neurother 2004; $4: 571-80$

33. Polman $\mathrm{CH}$, O'Connor PW, Havrdova E, Hutchinson M, Kappos L, Miller $\mathrm{DH}$, et al. A randomized, placebo-controlled trial of natalizumab for relapsing multiple sclerosis. N Engl J Med. 2006;354:899-910.

34. Hutchinson M, Kappos L, Calabresi PA, Confavreux C, Giovannoni G, Galetta SL, et al. The efficacy of natalizumab in patients with relapsing multiple sclerosis: subgroup analyses of AFFIRM and SENTINEL. J Neurol. 2009;256:405-15.

35. Bloomgren G, Richman S, Hotermans C, Subramanyam M, Goelz S, Natarajan A, et al. Risk of natalizumab-associated progressive multifocal leukoencephalopathy. N Engl J Med. 2012;366:1870-80.

36. Bellizzi A, Anzivino E, Rodio DM, Palamara AT, Nencioni L, Pietropaolo $\mathrm{V}$. New insights on human polyomavirus JC and pathogenesis of progressive multifocal leukoencephalopathy. Clin Dev Immunol. 2013;2013:839719.

37. Sørensen PS, Bertolotto A, Edan G, Giovannoni G, Gold R, Havrdova E, et al. Risk stratification for progressive multifocal leukoencephalopathy in patients treated with natalizumab. Mult Scler. 2012;18:143-52.

38. Biogen Idec. Global natalizumab (TYSABRI) safety update. 2014 April.

39. Fernández $\mathrm{O}$, García-Merino JA., Arroyo R, Alvarez-Cermeño JC, Izquierdo G, Saiz A, et al. Consenso español actualizado sobre el uso del natalizumab (Tysabri®)-2013. Neurologia. 2015;30:302-14.

40. Lee P, Plavina T,Castro A, Berman M, Jaiswal D, Rivas S, et al. A second-generation ELISA (STRATIFY JCV ${ }^{\mathrm{TM}}$ DxSelect ${ }^{\mathrm{TM}}$ ) for detection of JCvirusantibodies in humanserum and plasma to support progressive multifocal leukoencephalopathy risk stratification. J Clin Virol. 2013;57:141-6.

41. Warnke C, von Geldern G, Markwerth P, Dehmel T, Hoepner R, Gold $\mathrm{R}$, et al. Cerebrospinal fluid JC virus antibody index for diagnosis of natalizumab-associated progressive multifocal leukoencephalopathy Ann Neurol. 2014;76:792-801.

42. Post MJ, Yannoutsos C, Simpson D, Booss J, Clifford DB, Cohen B, et al. Progressive multifocal leukoencephalopathy in AIDS: are there any MR findings useful to patient management and predictive of patient survival? AJNR Am J Neuroradiol. 1999;20:1896-906. 
43. Yousem DM, Grossman RI. Neuroradiology: the requisites. $3^{\text {rd }}$ ed. Maryland Heights: Mosby; 2010

44. Thurnher MM, Judith M, Post D, Rieger A, Kleibl-Popov C, Loewe C, et al. Initial and follow-up MR imaging findings in AIDS-related progressive multifocal leukoencephalopathy treated with highly active antiretroviral therapy. AJNR Am J Neuroradiol. 2001;22:977-84

45. Major EO, Ault GS. Progressive multifocal leukoencephalopathy: clinical and laboratory observations on a viral induced demyelinating disease in the immunodeficient patient. Curr Opin Neurol. 1995;8:184-90.

46. Bernal-Cano F, Joseph JT, Koralnik IJ. Spinal cord lesions of progressive multifocal leukoencephalopathy in an acquired immunodeficiency syndrome patient. J Neurovirol. 2007;13:474-6.

47. Sweeney BJ, Manji H, Miller RF, Harrison MJ, Gray F, Scaravilli F. Cortical and subcortical JC virus infection: two unusual cases of AIDS associated progressive multifocal leukoencephalopathy. J Neurol Neurosurg Psychiatry. 1994;57:994-7.

48. Wattjes MP, Richert ND, Killestein J, de Vos M, Sanchez E, Snaebjornsson $\mathrm{P}$, et al. The chameleon of neuroinflammation: magnetic resonance imaging characteristics of natalizumab-associated progressive multifocal leukoencephalopathy. Mult Scler. 2013;19:182640.

49. Wattjes MP, Vennegoor A, Steenwijk MD, de Vos M, Killestein J, van Oosten BW, et al. MRI pattern in asymptomatic natalizumab-associated PML. J Neurol Neurosurg Psychiatry. 2015;86:793-8.

50. Wijburg MT, van Oosten BW, Murk JL, Karimi O, Killestein J, Wattjes MP. Heterogeneous imaging characteristics of JC virus granule cell neuronopathy (GCN): a case series and review of the literature. J Neurol. 2015;262:65-73.

51. Cosottini M, Tavarelli C, Del Bono L, Doria G, Giannelli M, De Cori S, et al. Diffusion-weighted imaging in patients with progressive multifocal leukoencephalopathy. Eur Radiol. 2008;18:1024-30

52. Huisman TA, Boltshauser E, Martin E, Nadal D. Diffusion tensor imaging in progressive multifocal leukoencephalopathy: early predictor for demyelination? AJNR Am J Neuroradiol. 2005;26:2153-6.

53. Usiskin SI, Bainbridge A, Miller RF, Jäger HR. Progressive multifocal leukoencephalopathy: serial high-b-value diffusion-weighted MR imaging and apparent diffusion coefficient measurements to assess response to highly active antiretroviral therapy. AJNR Am J Neuroradiol. 2007;28:285-6.

54. Menon DK, Ainsworth JG, Cox IJ, Coker RC, Sargentoni J, Coutts GA, et al. Proton MR spectroscopy of the brain in AIDS dementia complex. $J$ Comput Assist Tomogr. 1992;16:538-42.

55. Chong WK, Sweeney B, Wilkinson ID, Paley M, Hall-Craggs MA, Kendall $\mathrm{BE}$, et al. Proton spectroscopy of the brain in HIV infection: correlation with clinical, immunologic, and MR imaging findings. Radiology. 1993;188:119-24

56. Jarvik JG, Lenkiski RE, Grossman RI, Gomori JM, Schnall MD, Frank I. Proton MR spectroscopy of HIV infected patients: characterization of abnormalities with imaging and clinical correlation. Radiology. 1993;186:739-44.

57. Hurley RA, Ernst T, Khalili K, Del Valle L, Simone IL, Taber $\mathrm{KH}$. Identification of HIV-associated progressive multifocal leukoencephalopathy: magnetic resonance imaging and spectroscopy. J Neuropsychiatry Clin Neurosci. 2003;15:1-6.

58. Chang L, Ernst T, Tornatore C, Aronow H, Melchor R, Walot I, et al. Metabolite abnormalities in progressive multifocal leukoencephalopathy by proton magnetic resonance spectroscopy. Neurology. 1997;48:83645.

59. Katz-Brull R, Lenkiski RE, Du Pasquier RA, Koralnik IJ. Elevation of myoinositol is associated with disease containment in progressive multifocal leukoencephalopathy. Neurology. 2004;63:897-900.

60. Post MJ, Thurnher MM, Clifford DB, Nath A, Gonzalez RG, Gupta RK, et al. CNS-immune reconstitution inflammatory syndrome in the setting of HIV infection, part 1: overview and discussion of progressive multifocal leukoencephalopathy-immune reconstitution inflammatory syndrome and cryptococcal-immune reconstitution inflammatory syndrome. AJNR Am J Neuroradiol. 2013;34:1297-307.
61. DeSimone JA, Pomerantz $\mathrm{R}$, Babinchak $\mathrm{TJ}$. Inflammatory reactions in HIV- 1-infected persons after initiation of highly active antiretroviral therapy. Ann Intern Med. 2000;133:447-54.

62. Shelburne SA, Visnegarwala F, Darcourt J, Graviss EA, Giordano TP, White $\mathrm{AC} \mathrm{Jr}$, et al. Incidence and risk factors for immune reconstitution inflammatory syndrome during highly active antiretroviral therapy. AIDS 2005;19:399-406

63. Shelburne SA 3rd, Darcourt J, White AC Jr, Greenberg SB, Hamill $\mathrm{RJ}$, Atmar RL, et al. The role of immune reconstitution inflammatory syndrome in AIDS related Cryptococcus neoformans disease in the era of highly active antiretroviral therapy. Clin Infect Dis. 2005;40:1049-52.

64. D'Amico R, Sarkar S, Yusuff J, Azar E, Perlman DC. Immune reconstitution after potent antiretroviral therapy in AIDSpatients with progressive multifocal leukoencephalopathy. Scand J Infect Dis. 2007;39:347-50

65. Manabe YC, Campbell JD, Sydnor E, Moore RD. Immune reconstitution inflammatory syndrome: risk factors and treatment implications. J Acquir Immune Defic Syndr. 2007;46:456-62.

66. Riedel DJ, Pardo CA, McArthur J, Nath A. Therapy insight: CNS manifestations of HIV-associated immune reconstitution inflammatory syndrome. Nat Clin Pract Neurol. 2006;2:557-65.

67. Cinque P, Pierotti C, Viganò MG, Bestetti A, Fausti C, Bertelli D, et al. The good and evil of HAART in HIV related progressive multifocal leukoencephalopathy. J Neurovirol. 2001;7:358-63.

68. French MA. HIVIAIDS: immune reconstitution inflammatory syndrome-a reappraisal. Clin Infect Dis. 2009;48:101-7.

69. Tan K, Roda R, Ostrow L, McArthur J, Nath A. PML-IRIS in patients with HIV infection: clinical manifestations and treatment with steroids. Neurology. 2009;72:1458-64.

70. Yousry TA, Pelletier D, Cadavid D, Gass A, Richert ND, Radue EW, et al. Magnetic resonance imaging pattern in natalizumab-associated progressive multifocal leukoencephalopathy. Ann Neurol. 2012;72:77987.

71. Metz I, Radue EW, Oterino A, Kümpfel T, Wiendl H, Schippling S, et al. Pathology of immune reconstitution inflammatory syndrome in multiple sclerosis with natalizumab-associated progressive multifocal leukoencephalopathy. Acta Neuropathol. 2012;123:235-45.

72. Wenning W, Haghikia A, Laubenberger J, Clifford DB, Behrens PF Chan A, et al. Treatment of progressive multifocal leukoencephalopathy associated with natalizumab. N Engl J Med. 2009;361:1075-80.

73. Koralnik IJ. Neurologic diseases caused by human immunodeficiency virus type 1 and opportunistic infections. In Mandell G, Bennett J, Dolin R. Mandell, Douglas and Bennett's principles and practice of infectious diseases. Volume 2. $7^{\text {th }}$ ed. London: Churchill Livingstone Elsevier; 2010

74. Nelson M, Manji H, Wilkins E. Central nervous system opportunistic infections. British HIV Association and British Infection Association Guidelines for the treatment of opportunistic infection in HIV-seropositive individuals 2011. HIV Med. 2011;12:S1-140.

75. Giacomini PS, Metz I, Araujo D, Arbour N, Bar-Or A. Maraviroc and JC virus-associated immune reconstitution inflammatory syndrome. $\mathrm{N}$ Eng J Med. 2014;370:486-8

76. Antoniol C, Jilek S, Schluep M, Mercier N, Canales M, Le Goff G, et al. Impairment of JCV specific T-cell response by corticotherapy: effect on PML-IRIS management? Neurology. 2012;79:2258-64.

77. Berger JR, Pall L, Lanska D, Whiteman M. Progressive multifocal leukoencephalopathy in patients with HIV infection. J Neurovirol. 1998;4:59-68.

78. De Luca A, Giancola ML, Ammassari A, Grisetti S, Paglia MG, Gentile $M$, et al. The effect of potent antiretroviral therapy and JC virus load in cerebrospinal fluid on clinical outcome of patients with AIDSassociated progressive multifocal leukoencephalopathy. J Infect Dis. 2000;182:1077-83.

79. Berenguer J, Miralles P, Arrizabalaga J, Ribera E, Dronda F, BaraiaEtxaburu J, et al. Clinical course and prognostic factors of progressive multifocal leukoencephalopathy in patients treated with highly active antiretroviral therapy. Clin Infect Dis. 2003;36:1047-52. 
Luís AUGUSTO, Nélia NEVES, Carina REIS, Cândida ABREU, António SARMENTO

\section{Clinical and Radiological Characterization of Progressive Multifocal Leukoencephalopathy in HIV-Infected Patients: A Retrospective Analysis and Review of the Literature}

Acta Med Port 2015:28:286-296

Publicado pela Acta Médica Portuguesa, a Revista Científica da Ordem dos Médicos

Av. Almirante Gago Coutinho, 151

1749-084 Lisboa, Portugal.

Tel: +351218428 215

E-mail: submissao@actamedicaportuguesa.com

www.actamedicaportuguesa.com

ISSN:0870-399X | e-ISSN: 1646-0758

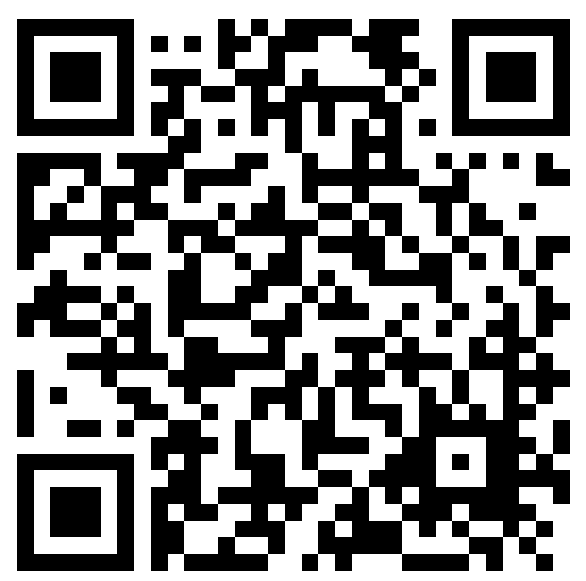

